\title{
Mechanical Properties of High-Performance Hybrid Fibre-Reinforced Concrete at Elevated Temperatures
}

\author{
Moawiah Mubarak ${ }^{1, *}$, Raizal Saifulnaaz Muhammad Rashid ${ }^{1}$, Mugahed Amran ${ }^{2,3, *(D), ~ R o m a n ~ F e d i u k ~}{ }^{4}$ (D), \\ Nikolai Vatin ${ }^{5}$ (D) and Sergey Klyuev ${ }^{6}$ (D)
}

1 Department of Civil Engineering, Faculty of Engineering, Universiti Putra Malaysia, Serdang 43400, Malaysia; raizal@upm.edu.my

2 Department of Civil Engineering, College of Engineering, Prince Sattam Bin Abdulaziz University, Al-Kharj 11942, Saudi Arabia

3 Department of Civil Engineering, Faculty of Engineering and IT, Amran University, Quhal, Amran 9677, Yemen

4 Polytechnic Institute, Far Eastern Federal University, 690922 Vladivostok, Russia; fedyuk.rs@dvfu.ru

5 Peter the Great St. Petersburg Polytechnic University, 195251 St. Petersburg, Russia; vatin@mail.ru

6 Department of Theoretical Mechanics and Strength of Materials, Belgorod State Technological University Named after V.G. Shukhov, 308012 Belgorod, Russia; klyuyev@yandex.ru

* Correspondence: moawiah.mubarak94@gmail.com (M.M.); m.amran@psau.edu.sa (M.A.)

\section{check for}

updates

Citation: Mubarak, M.;

Muhammad Rashid, R.S.; Amran, M.;

Fediuk, R.; Vatin, N.; Klyuev, S.

Mechanical Properties of

High-Performance Hybrid

Fibre-Reinforced Concrete at Elevated Temperatures. Sustainability 2021, 13,

13392. https://doi.org/10.3390/

su132313392

Academic Editors: Zheng Lu,

Jiafei Jiang and Tengfei Fu

Received: 27 July 2021

Accepted: 20 September 2021

Published: 3 December 2021

Publisher's Note: MDPI stays neutral with regard to jurisdictional claims in published maps and institutional affiliations.

Copyright: (c) 2021 by the authors. Licensee MDPI, Basel, Switzerland. This article is an open access article distributed under the terms and conditions of the Creative Commons Attribution (CC BY) license (https:// creativecommons.org/licenses/by/ $4.0 /)$.

\begin{abstract}
Deterioration of concrete's integrity under elevated temperature requires an alteration in its composition to have better thermal stability. Fibre-reinforced concrete has shown significant improvements in concrete strength and this paper aimed to investigate the influence of steel (ST) and polypropylene (PP) fibres on the behaviour of high-performance concrete (HPC) exposed to elevated temperatures. Six mixtures were prepared and cast by adding one or two types of polypropylene fibre (54 and $9 \mathrm{~mm}$ ) at 0.25 or $0.5 \%$ and either singly or in a hybrid combination, along with a fixed volumetric content at $1 \%$ of five-dimensional hooked steel $(5 \mathrm{DH})$ fibres. At the age of 28 days, samples were heated to the targeted temperature of $800{ }^{\circ} \mathrm{C}$ and cooled down naturally to the laboratory temperature. Visual inspection, flexural, split tensile and compressive strengths were examined before and after the exposure to elevated temperatures. Results exhibited that the hybridization of long and short PP fibres, along with the ST fibres, has notably improved all residual mechanical properties of HPC and kept the integrity of concrete after exposure to elevated temperatures. In addition, PP fibres can significantly prevent spalling, but ST fibres were ineffective in mitigating explosive spalling in beams specimens.
\end{abstract}

Keywords: elevated temperatures; high-performance concrete; hybrid fibre; thermal resistance; steel and polypropylene fibres; mechanical properties

\section{Introduction}

The production improvement on the mechanical properties of high-performance concrete (HPC) is recently acknowledged as a remarkable research advancement compared to normal concrete, which enables a variety of structures, that require high mechanical strength, durability, flowability, ductility and the ease of casting the concrete to be constructed [1]. Recent research incorporating hybrid fibres in the concrete mix showed significant improvements in the split tensile strength, toughness [2,3], flexural strength and preventing crack propagation (plastic and drying shrinkage) [4-7]. The addition of polypropylene fibres in concrete has shown an improvement in the splitting tensile and flexural strength, but not in terms of compressive strength [8,9]. Another common fibre used in research is steel fibres which leads to an increase in concrete's overall mechanical properties such as impact resistance [10,11], ductility [12,13], tensile [2,14] and flexural [15] strengths, and resistance towards crack propagation [16-19]. The hybridization of steel and propylene fibre is utilized to deliver a balanced enhancement in concrete and the primary 
purposes of adding two different lengths (short and long) of fibres are to enhance the ductility and tensile strength by the action of these fibres [20-22]. Furthermore, the aspect ratio of the fibre influences the ductility and tensile strength of the concrete [20]. The mix design of HPC requires using superplasticizer, the lowest possible water to binder ratio, and may contain mineral admixtures such as silica fume, Metakaolin and fly ash which densifies its microstructure [23-25].

The sensitivity of concrete towards fire accidents helped shape the recent studies and showed that elevated temperatures and fires caused deterioration in terms of the spalling of concrete $[8,26,27]$ and the adverse change in its microstructure $[23,24]$. Degradation, such as the spalling, leads to the exposure of embedded reinforcement steel and the reduction of the concrete and steel cross-section, which results in load capacity loss of structural elements and an eventual failure of the entire structures [28-31]. This loss of integrity at high temperature in HPC is due to densely packed microstructure resulting from the pore pressure development mechanism [32,33] and brittle fracture mechanism due to the thermal gradient [34]. Many experimental studies conducted by different authors [35,36] proved that adding polypropylene fibres has enhanced the thermal stability of HPC by mitigating the spalling of concrete. Polypropylene fibres melt at a low melting point $\left(160-180^{\circ} \mathrm{C}\right)$ and leave many random channels inside the concrete matrix. These channels can decrease the vapour pressure and reduce the probability of spalling [37] and this is not possible with steel fibres $[38,39]$. However, a study shows that steel fibres can release vapor pressure throughout the pores during exposure to elevated temperatures [40,41] and delay the occurrence of spalling to a certain degree without eliminating the phenomena [42]. In terms of residual mechanical properties of concrete exposed to elevated temperatures, several studies indicate a positive influence on the residual compressive, flexural and splitting tensile strengths after utilizing a hybrid mix of steel and propylene fibres [43-46], while few studies showed otherwise [37,47-50]. Overall, it can be seen that the previous studies on the residual strength of HPC containing propylene and steel fibres show contradictory conclusions, and the study of thermal behaviour of concrete containing long and short polypropylene fibres, along with hooked steel fibres, is neither clear nor has a solid reported finding. Therefore, this paper aims to utilize the hybridization of steel and propylene fibre in the composition to optimize the enhancement in concrete's thermal resistance in terms of mechanical properties and visual inspections (cracks and spalling). The study was conducted on six mixtures, using a heat treatment furnace with a stainless steel cage to protect its heating elements. Additionally, the effect of different lengths (short and long) of polypropylene fibres on concrete is also investigated.

\section{Experimental Programs}

\subsection{Materials and Mix Composition}

Ordinary Portland cement (OPC) of grade 40, provided by Tasek Corporation Berhad and conforming to ASTM C150M-15 [51], was used. The specific gravity of cement was found to be 3.15. Properties of cement are shown in Table 1. The silica fume used in this study is dry densified micro silica powder under the name of FORCE 10,000 D, which is produced by Grace Construction Products and complied with ASTM C1240-20 [52] (Table 1). Sand and coarse aggregate (crushed stone) used in this study complied with ASTM C33 [53] standards for sieve analysis and their size distribution are shown in Figures 1 and 2. The sand's specific gravity and water absorption are 2.52 and $1.68 \%$, respectively, while the coarse aggregate had a specific gravity of 2.65 and water absorption of $0.88 \%$, with a maximum size of $10 \mathrm{~mm}$. 
Table 1. Properties of cement and silica fume.

\begin{tabular}{cccc}
\hline \multicolumn{1}{c}{ Cement } & \multicolumn{2}{c}{ Silica Fume } \\
\hline \multicolumn{2}{c}{ Chemical Composition (\%) } & \multicolumn{2}{c}{ Chemical Composition (\%) } \\
\hline $\mathrm{CaO}$ & 64.64 & $\mathrm{CaO}$ & 0.91 \\
$\mathrm{SiO}_{2}$ & 21.28 & $\mathrm{SiO}_{2}$ & 91.6 \\
$\mathrm{Al}_{2} \mathrm{O}_{3}$ & 5.6 & $\mathrm{Al}_{2} \mathrm{O}_{3}$ & 1.69 \\
$\mathrm{Fe}_{2} \mathrm{O}_{3}$ & 3.36 & $\mathrm{Fe}_{2} \mathrm{O}_{3}$ & 1.68 \\
$\mathrm{MgO}_{\mathrm{SO}}$ & $\mathrm{MgO}$ & - \\
$\mathrm{N}_{3} \mathrm{O}$ & 2.06 & $\mathrm{SO}$ & 0.33 \\
Loss Ignition & 2.14 & $\mathrm{~K}_{2} \mathrm{O}$ & 1.19 \\
Lime saturation factor & 0.05 & $\mathrm{LOI}$ & 2.75 \\
$\mathrm{C}_{3} \mathrm{~S}$ & 0.64 & $\mathrm{~S} . \mathrm{G}$ & 2.26 \\
$\mathrm{C}_{2} \mathrm{~S}$ & 0.92 & - & - \\
$\mathrm{C}_{3} \mathrm{~A}$ & 52.82 & - & - \\
$\mathrm{C}_{4} \mathrm{AF}$ & 21.45 & - & - \\
\hline
\end{tabular}

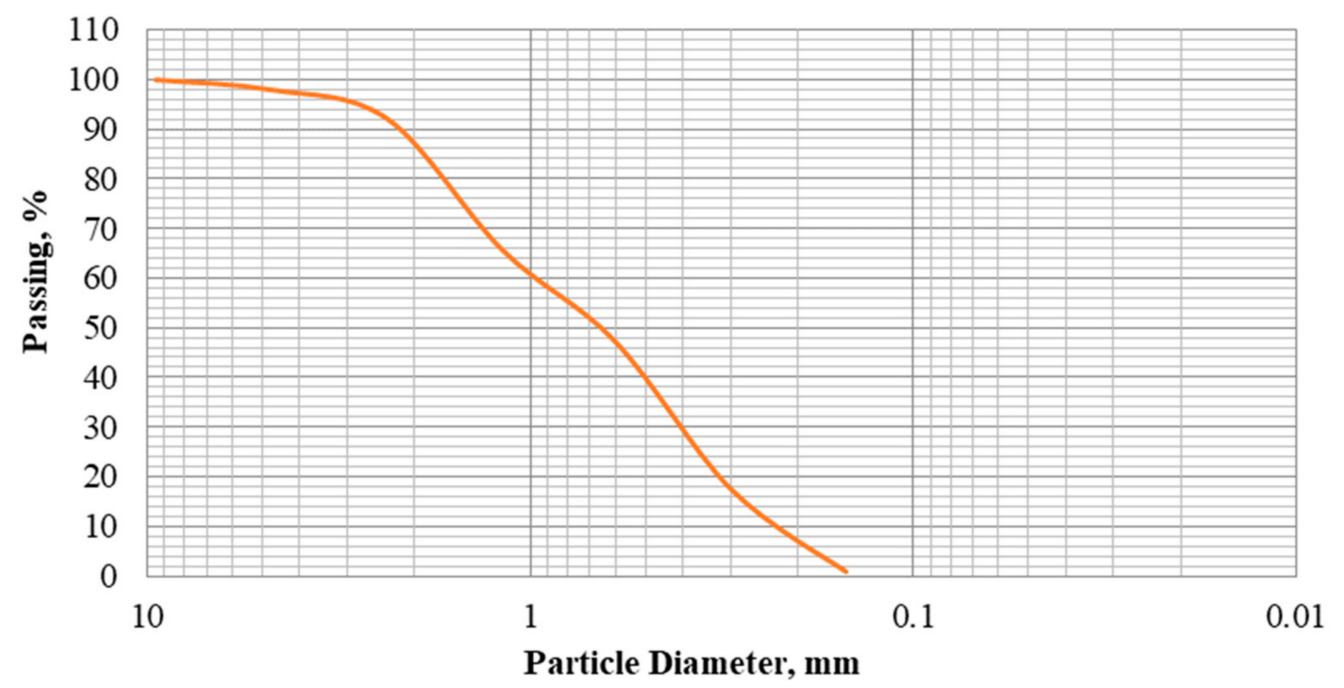

Figure 1. Sand particles size distribution curve.

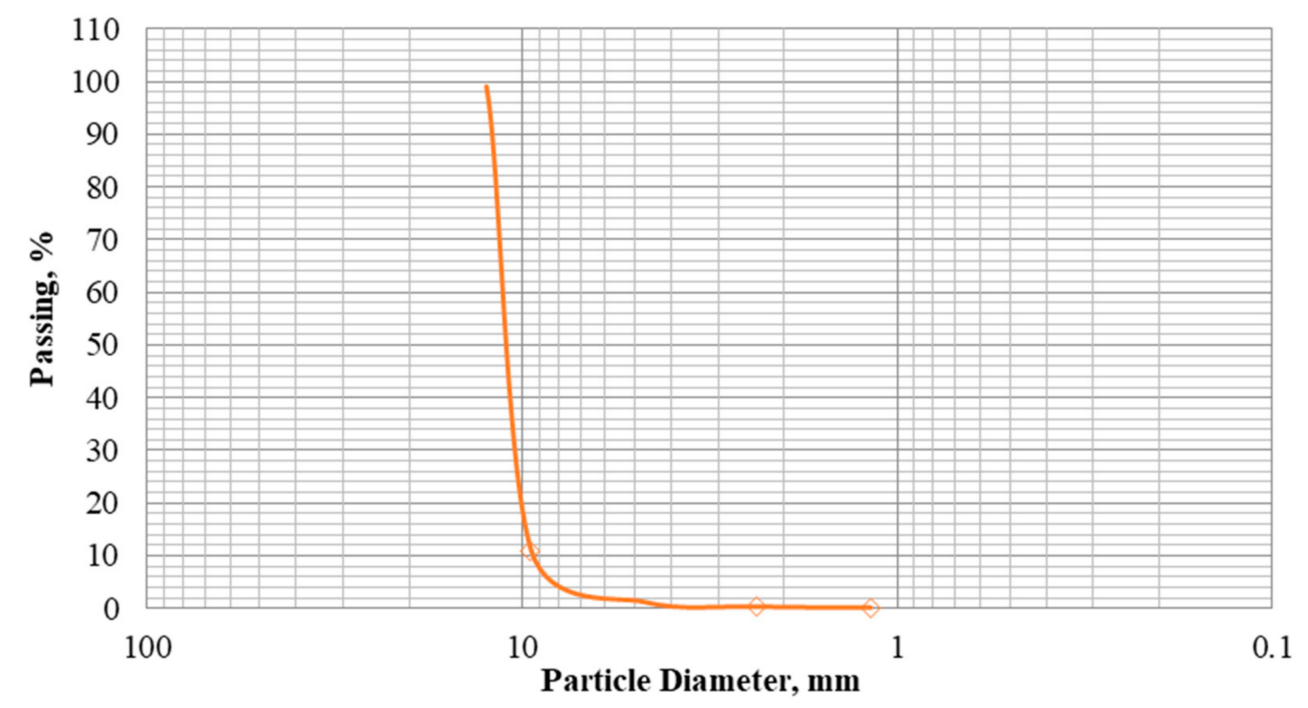

Figure 2. Coarse Aggregate particles size distribution curve. 
Two different lengths and types of propylene fibres produced by Forta Corporation were used (Figure 3a,b). The short polypropylene fibre (PS) is made of $100 \%$ virgin photopolymer in a collated fibrillated form with an average length of $9 \mathrm{~mm}$. The long polypropylene monofilaments fibre (PL) is made of Virgin Copolymer with a length of $54 \mathrm{~mm}$. Both fibres have a tensile strength of $660 \mathrm{MPa}$ and specific Gravity of 0.91 with a melting point of $160^{\circ} \mathrm{C}$. The improved five-dimensional hooked (5DH) type produced by Bekaert Corporation was used (Figure 3c). The steel fibres have a length of $60 \mathrm{~mm}$ with high tensile strength of 2,300 MPa. The density and the aspect ratio (length/diameter) are $7800 \mathrm{~kg} / \mathrm{m}^{3}$ and 65, respectively. A large-scale water-reducing agent (ADVA cast 512) was used and was provided by GCP Applied Technologies with a density of $1.06 \mathrm{~kg} / \mathrm{m}^{3}$. Six different HPC mixtures were prepared (Table 2). Four of the mixtures were designed to contain short or/and long propylene fibres at a volumetric fraction of 0.25 or $0.5 \%$ with $1 \%$ of five-dimensional hooked steel fibres, one mixture of plain HPC (Control mix) and a mixture with only $1 \%$ of steel fibres because this percentage showed a significant improvement in the concrete's mechanical performance [54].The samples were subjected to a temperature of $800^{\circ} \mathrm{C}$, and the thermo-mechanical properties were studied in terms of visual inspection, mass loss, compressive, split tensile and flexural strength. Six mixes were made using a water-to-binder ratio of 0.43 with silica fume replacing $10 \%$ of the cement's weight to achieve a higher strength. Super-plasticizer was varied from $2.2 \%$ to $2.4 \%$ by the weight of cement for better workability. The mix design of the plain concrete (M1); concrete with no fibres, is designed according to the absolute volume method given by ACI [55], with the addition of steel and polypropylene fibres and was examined by [56]. The steel fibres were added to the mixes according to a fixed volumetric fraction of $1.0 \%$ (mixes M2-M6), while Single and hybrid (long and short) polypropylene fibres were added at volumetric fractions of 0.125 and 0.25 (mixes M2-M5).

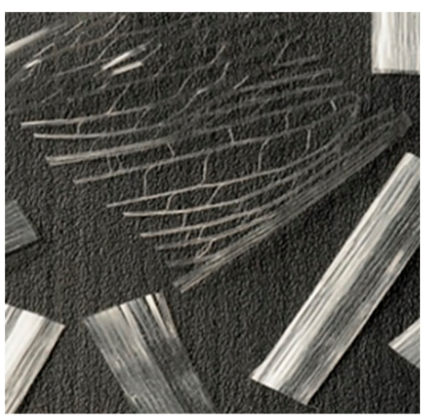

(a)

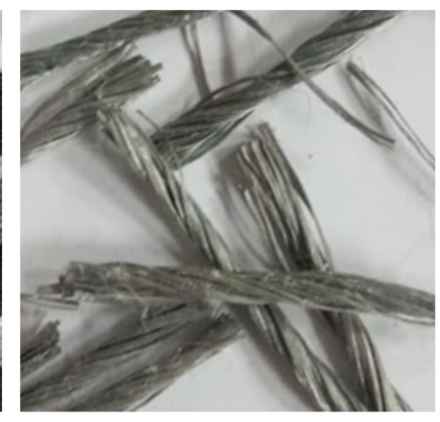

(b)

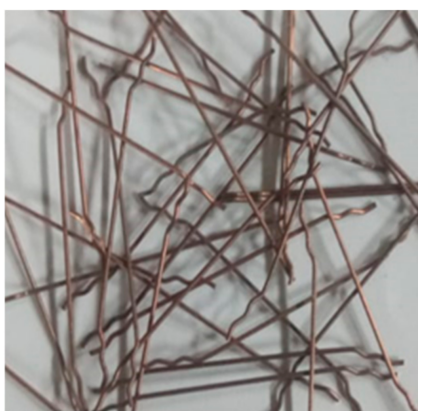

(c)

Figure 3. (a) Short polypropylene fibre (b) long polypropylene fibre (c) 5DH steel fibres.

Table 2. Mix composition of all samples.

\begin{tabular}{cccccccccc}
\hline Mix & \multicolumn{4}{c}{ Mix Proportions $\mathbf{( K g / \mathbf { m } ^ { 3 } )}$} & \multicolumn{3}{c}{ Mix Proportions (\%) } \\
\hline & $\begin{array}{c}\text { Silica } \\
\text { Fume }\end{array}$ & Cement & Sand & $\begin{array}{c}\text { Coarse } \\
\text { Aggregate }\end{array}$ & Water & Superplasticizer & ST & PL & PS \\
\hline M1 & 50 & 500 & 880 & 710 & 235 & 2.2 & 0 & 0 \\
M2 & 50 & 500 & 880 & 710 & 235 & 2.2 & 1 & 0.125 & 0.125 \\
M3 & 50 & 500 & 880 & 710 & 235 & 2.2 & 1 & 0.25 & 0 \\
M4 & 50 & 500 & 880 & 710 & 235 & 2.2 & 1 & 0.25 \\
M5 & 50 & 500 & 880 & 710 & 235 & 2.4 & 1 & 0.25 & 0.25 \\
M6 & 50 & 500 & 880 & 710 & 235 & 2.2 & 1 & 0 \\
\hline
\end{tabular}

A total of 108 specimens were cast, 36 specimens for each test. The concrete was mixed in a mechanical laboratory concrete mixer and cast into $100 \times 100 \times 100 \mathrm{~mm}$ cubes, $100 \times 200 \mathrm{~mm}$ cylinders and $100 \times 100 \times 500 \mathrm{~mm}$ beams. Moulds were cast in two equal 
layers and vibrated by using a mechanical vibrating table for $30 \mathrm{~s}$. The specimens were kept in moulds for $24 \mathrm{~h}$ under lab conditions and then de-moulded and immersed in a water tank for 28 days at $27^{\circ} \mathrm{C}$.

\subsection{Heating and Cooling Regime}

After curing, the samples were left outside the water tank for one day before being exposed to an elevated temperature in a chamber furnace (Figure 4a). The maximum targeted temperature of $800^{\circ} \mathrm{C}$ was reached at a heating rate of $13.3^{\circ} \mathrm{C} / \mathrm{min}$. The temperature of natural and accidental fires can reach $1000^{\circ} \mathrm{C}$ [28] but $800^{\circ} \mathrm{C}$ was chosen in most of the studies, including this paper, because concrete loses almost all compressive strength at $800{ }^{\circ} \mathrm{C}$ [29], and this temperature satisfies the practical assessment [30]. After reaching the required temperature, the specimens were kept inside the furnace with a constant temperature of $800{ }^{\circ} \mathrm{C}$ for $90 \mathrm{~min}$ to ensure the samples' integrity [57] and a uniform heating among them.

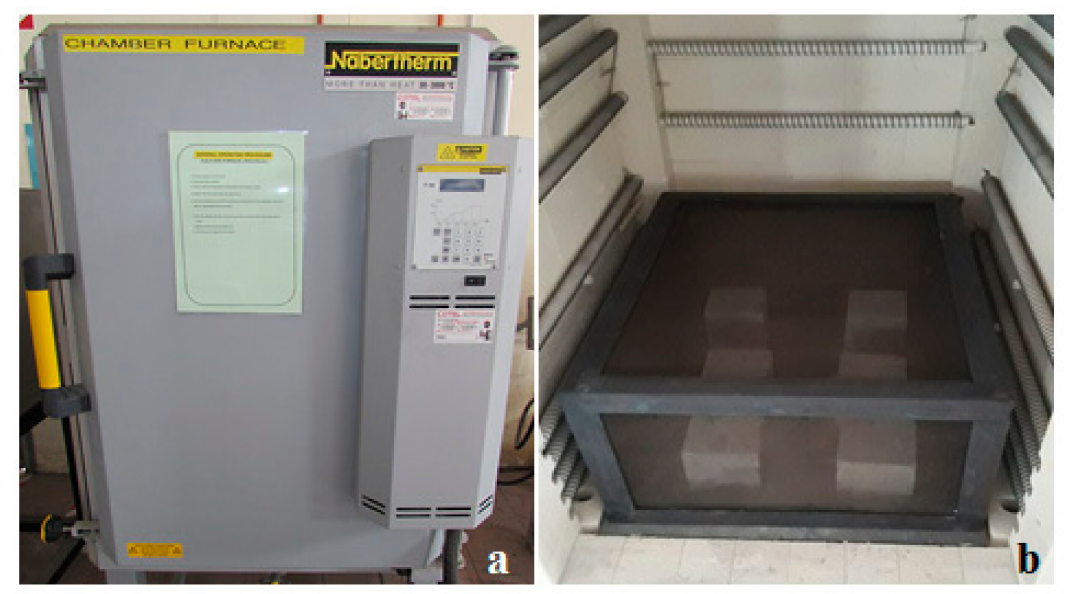

Figure 4. (a) The electrical furnace and (b) heat resistance steel cage.

Then the temperature was decreased gradually in the furnace. After the heating cycle finished, Samples were cooled down naturally outside the furnace at room temperature for $24 \mathrm{~h}$ before testing. A novel methodology in operating the heating treatment furnace was used in this study, in which a heat resistant steel cage with a heat resistant stainless-steel mesh was used to protect the heating elements from any possible explosion due to the spalling of concrete during the heating process (Figure $4 \mathrm{~b}$ ). Figure 5 shows the heating and cooling cycle curve.

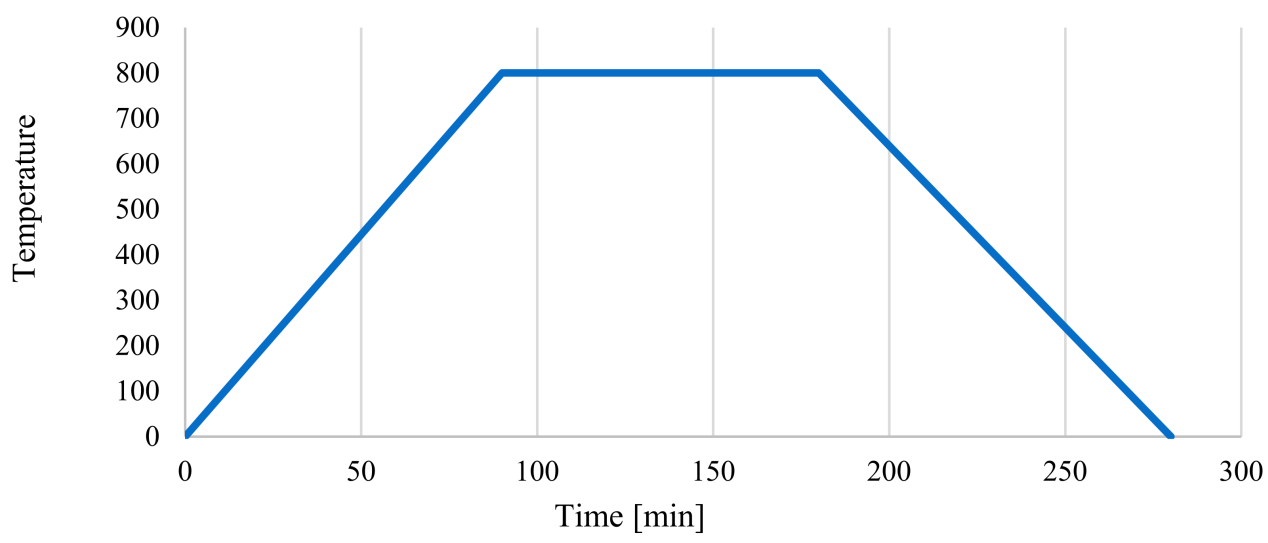

Figure 5. Measured temperature-time curve of the furnace. 


\subsection{Mass Loss}

Samples were let to cool down to room temperature freely without spraying water on the surface. The amount of mass loss during the heating was measured and recorded in percentage. Only the average weight of three beams before and after the exposure to a temperature of $800^{\circ} \mathrm{C}$ was measured and the ratio of reduction to the original weight represents the loss in mass.

\subsection{Mechanical Properties Tests}

For split tensile strength, the $200 \times 100 \mathrm{~mm}$ cylinder was placed with its horizontal axis between the plates of the testing machine and tested according to ASTM C496 [58] with a constant loading rate of $1.57 \mathrm{KN}$ per second. The flexural test was also performed by the four Points Flexural bend test machine (Figure 6a), in accordance with ASTM C78 [59], at a deflection rate of $0.1 \mathrm{~mm} / \mathrm{min}$ until the failure of the $100 \times 100 \times 500 \mathrm{~mm}$ beam (Figure $6 \mathrm{~b}$ ). Regarding the compressive strength test, the $100 \times 100$ cubes were tested according to BS EN 12390-3 [60] with a constant loading rate of $5.7 \mathrm{KN}$ per second, which was applied until the failure of the specimen. The mean value of three samples (cubes, cylinders and beams) at both temperatures for each mix was obtained.

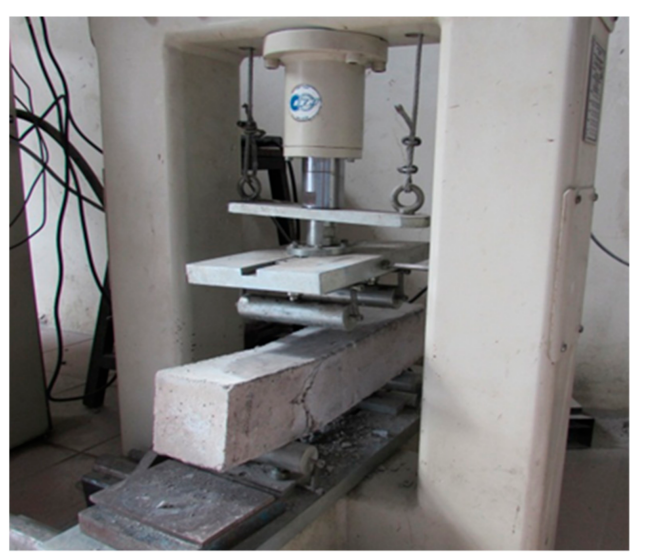

(a)

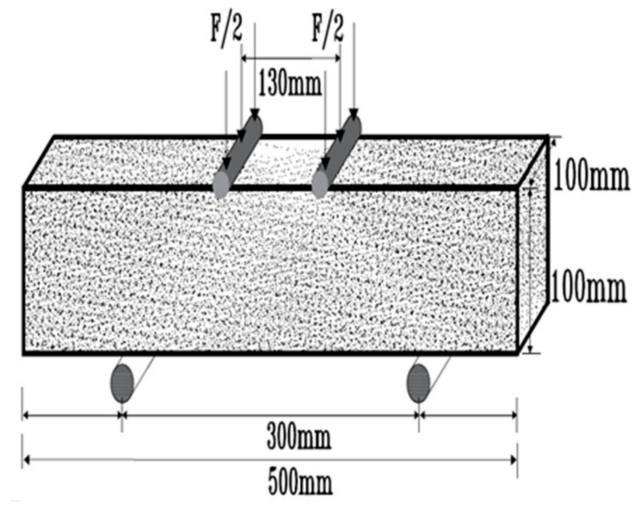

(b)

Figure 6. (a) Bending experimental test set-up (b) Specimens' dimensions and testing geometry.

\section{Results and Discussion}

\subsection{Mass Loss}

The mix with the highest fibre content (M5) showed the highest loss in mass (11.3\%), followed by M4 at 10.15\% (Figure 7). In contrast, the control mix (M1) had the lowest loss in mass among the other mixes, as it does not contain any fibres to create channels. M2, M3 and M6 had almost the exact percentages at 8.33, 7.83 and 7.4\%, respectively. M6 showed that steel fibres caused a negligible increase in loss percentage by $0.5 \%$ because steel fibres do not melt at $800{ }^{\circ} \mathrm{C}$. PP fibre with a larger aspect ratio also has a lower impact on mass loss, with an increase of only $0.9 \%$, as shown by specimen M3. However, shorter PP fibre created more connected channels, enabling more capillary and gel water to evaporate, and showed an increase by $3.25 \%$ in mass loss compared to the control mix. As expected, increasing fibre content gave the highest mass loss. The loss in mass will influence the mechanical properties of concrete [61-63], especially the tensile strength because it is more sensitive to the voids. 


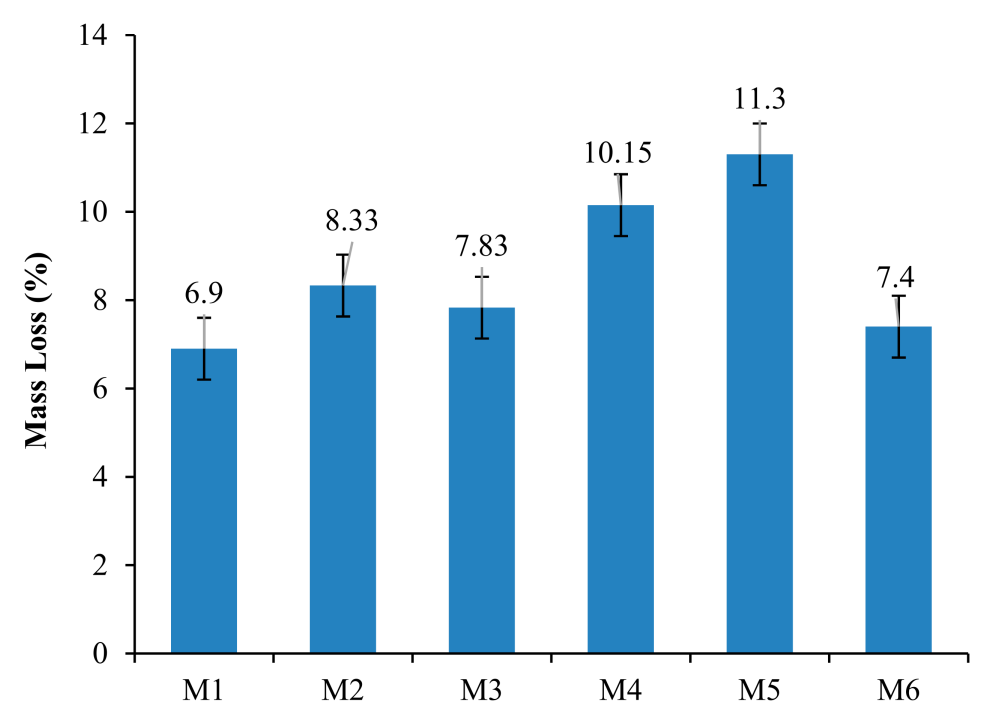

Figure 7. Loss of mass for beams (\%).

\subsection{Cracks and Spalling}

Regarding the phenomena of spalling, the spalling of four beams (two specimens for each mix) occurred in both plain concrete and concrete mixed with steel fibres (M6), and the spalling was extended beyond the surface due to the high packed density (Figure 8a). This finding was also reported by Hertz [64] who stated that steel fibres did not contribute to avoid the spalling phenomena after exposure to elevated temperatures. However, the steel cage protected the heating elements of the furnace after the exploding of the beam inside the furnace (Figure $8 \mathrm{~b}$ ).

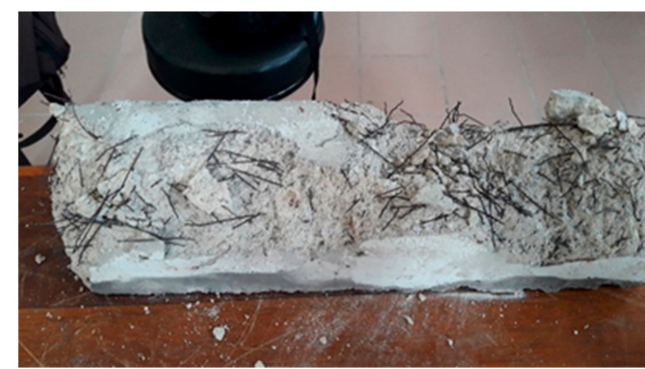

(a)

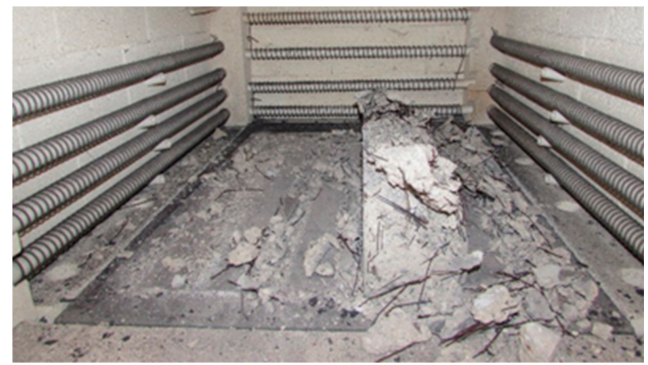

(b)

Figure 8. (a) Explosive spalling of M6 beam (b) Explosive spalling of M6 beam inside the furnace.

Adding PP fibres at $0.5 \%$ (either singly or in a hybrid combination) played an essential role in mitigating the spalling completely because these channels release vapour pressure and leave enough space for particles to expand without creating excessive stresses. The exposure to $800^{\circ} \mathrm{C}$ changed the concrete cube's surface colour to a dusty colour in cubes (Figure 9) or brownish/pinkish grey in cylinders (Figure 10). It is also noted that the colour of all samples was similar after the heating test, regardless of the amount or length of PP fibre incorporated. Stains of rust appeared on the concrete surface because of the oxidation of steel fibre that is out of the surface. PP fibres affected the appearance of concrete after the exposure as the fibres melted at a temperature above $160^{\circ} \mathrm{C}$. Incorporating shorter PP fibres reduced the amount of thermal cracking at the concrete's surface, as shown in cube and cylinder samples (Figures 9 and 10). 


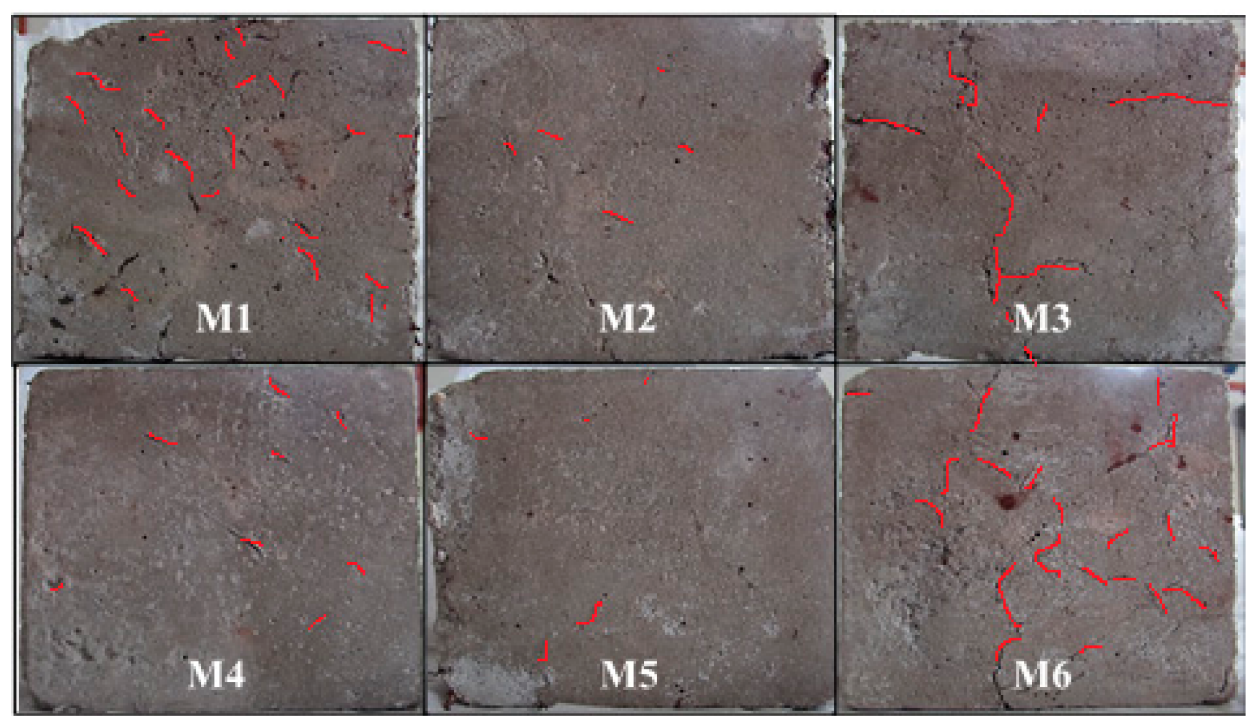

Figure 9. Change in colour and cracking pattern after the exposure to the $800{ }^{\circ} \mathrm{C}$.

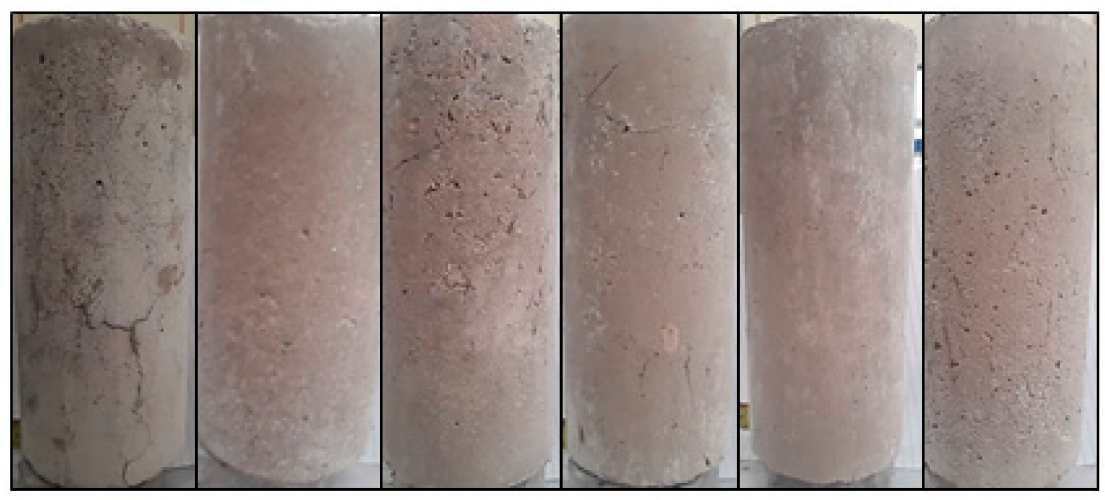

Figure 10. Change in colour and cracking pattern after the exposure to the $800{ }^{\circ} \mathrm{C}$.

Visibly, the amount of thermal cracking is more prominent in the mixture with no fibre (M1), mixtures with only steel fibres (M6) and samples having longer PP fibre (M3), which shows that short PP fibre is more effective in reducing thermal cracking compared to long PP fibre because they are more efficient in releasing internal vapor pressure.

\subsection{Compressive Strength}

Regarding the failure mechanism of unheated samples, the addition of PP fibres has an insignificant influence on the compressive failure mechanism at normal temperatures (Figure 11) with non-explosive mode for all specimens, but after the exposure, all samples experienced major cracking on the four faces instead of minor ones, with only M1 and M2 having a semi explosive failure where aspect ratio resisted deformation better by bridging the voids.

Incorporating $5 \mathrm{DH}$ steel fibre in the specimen (M6) resulted in a $4.2 \%$ increment in compressive strength compared to samples without fibres (M1) because of the confinement effect of steel fibres throughout the concrete matrix. The specimen with Long PP fibre (M3) gave the highest compressive strength among the PP fibre reinforced concrete, followed by hybridization in M2, which shows that fibres with a higher aspect ratio resist deformation better by bridging the voids. Using short PP fibre at $0.25 \%$ recorded the highest reduction in compressive strength. Increasing the inclusion of hybrid PP fibre from 0.25 to $0.5 \%$ resulted in a $43 \%$ reduction in compressive strength as shown by M5, and this decrease in strength is caused by the weak bond strength and decrease in density of the mix [65]. Regarding the residual strength of heated concrete, the hybridization of short and long 
propylene fibres at $0.5 \%$ gave the best performance in terms of retained strength at almost $40 \%$. However, the actual value (15.1 MPa) of compressive strength is the lowest among other mixtures. The mixture without any fibre lost nearly $82 \%$ of its strength and recorded the most insufficient residual compressive strength at only 11.6 MPa.

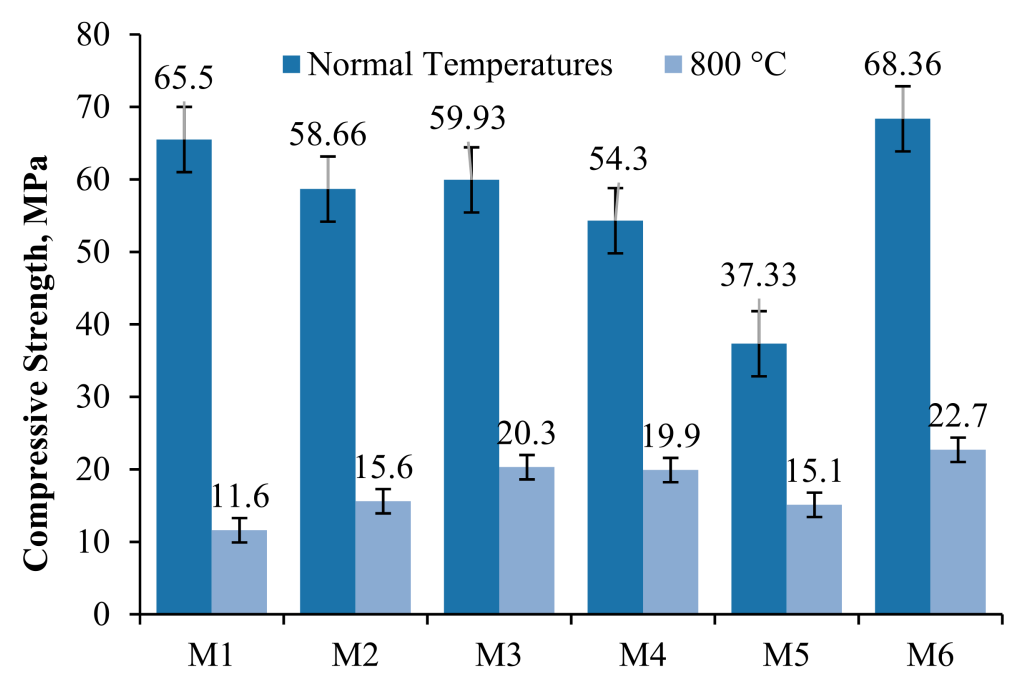

Figure 11. Compressive strength at normal and elevated temperatures.

Despite not having the highest retained strength, the mixture with only 5DH steel fibres gave the highest compressive strength (22.7 MPa) (Figure 12) because they prevent the expansion of the concrete matrix and decrease the temperature differences inside the concrete due to their high heat transfer coefficient. Short PP fibres at $0.25 \%$ had the most balanced performance at elevated temperatures in terms of residual percentage and compressive strength $(19.9 \mathrm{MPa})$. On the other hand, long PP fibre gave a reasonably good strength at $20.3 \mathrm{MPa}$, compared to the poor performance of M2. Figure 13 shows (a) failure mode of cubes at normal temperature and (b) after the exposure to $800^{\circ} \mathrm{C}$.

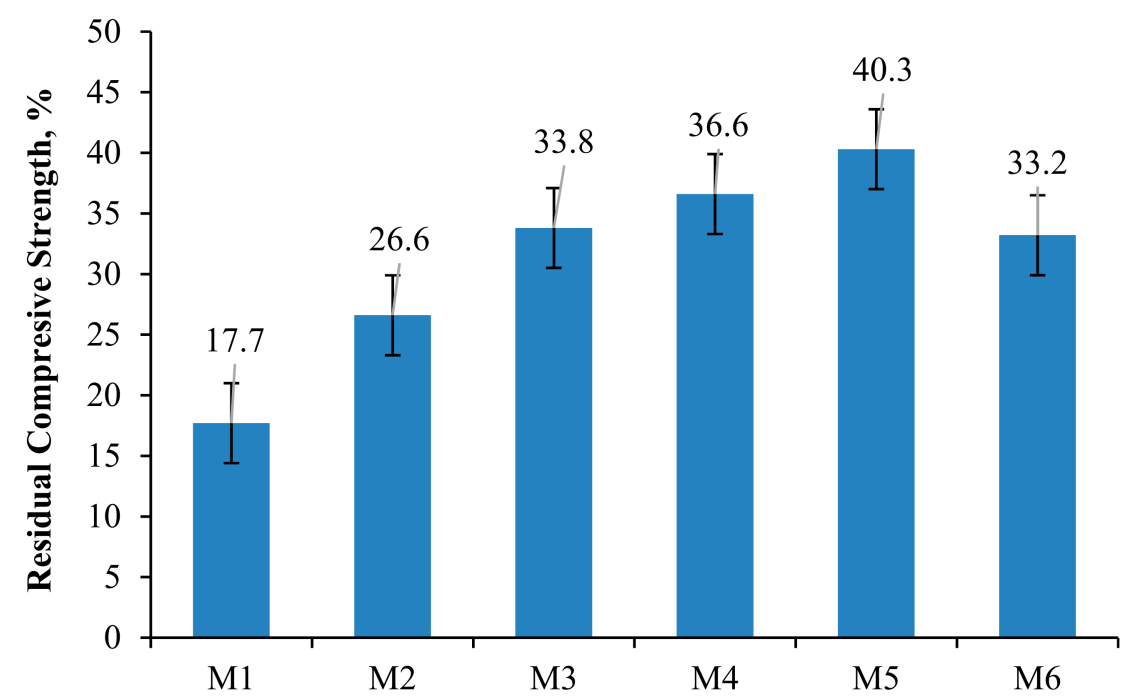

Figure 12. Residual compressive strength. 


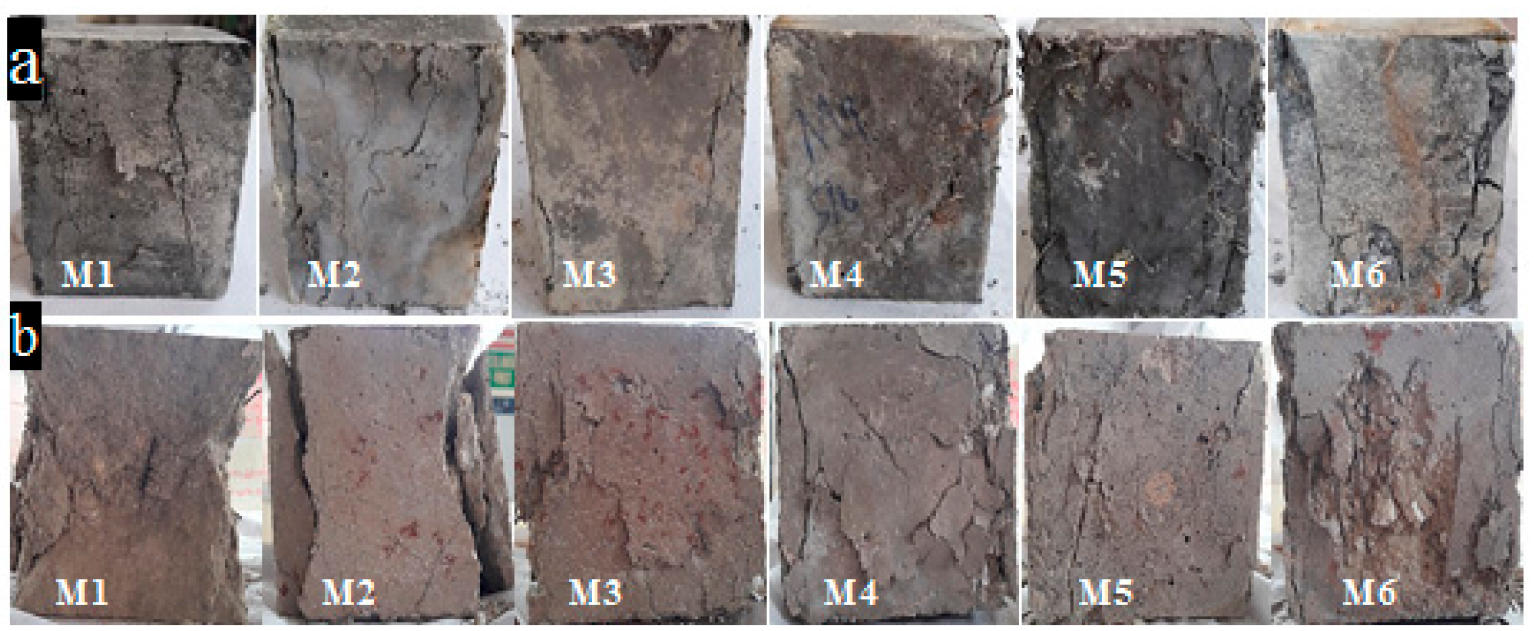

Figure 13. (a) Failure mode of cubes at normal temperature and (b) after the exposure to $800{ }^{\circ} \mathrm{C}$.

\subsection{Split Tensile Strength}

For the tensile failure mechanism, containing no fibres in concrete resulted in a brittle behaviour, as shown in M1. Similarly, fibre-reinforced specimens (M2-M6) had a brittle failure mode but with a fibre bridging effect along the failure line (Figure 14a). Thermally damaged plain concrete specimens (M1) broke into two equal parts (Figure 14b), while the other mixtures (M2-M6) had a ductile failure with more distributed cracks which can be seen clearly in M3. For the unheated specimens, the control mix had the lowest tensile strength at $1.63 \mathrm{MPa}$, as expected (Figure 15). The inclusion of 5DH steel fibres in the concrete showed a significant increase of $105 \%$ in the split tensile strength compared to the control one because of the anchoring mechanism developed by the triple-end hooks, which increase the bond strength of fibres, hence increasing the tensile strength of the concrete [66]. The hybridisation of 5DH steel and PP fibres showed a considerable increase in tensile strength and adding them at a percentage of $1 \%$ and $0.125 \%$, respectively, gave the highest strength at $3.92 \mathrm{MPa}$. These outcomes support the idea that fibres will be activated when the crack plane is opposite to the fibres. Both mixtures (M3 and M4) recorded a slight decrease in tensile strength at $3.17 \mathrm{MPa}$ and $2.95 \mathrm{MPa}$, respectively compared to M6. A further increase in the percentage of PP fibres in the mix (M5) resulted in the lowest tensile strength because tensile strength is more sensitive toward voids. The effect of fibres in concrete is more pronounced in heated specimens. The addition of $0.125 \%$ PP fibres in the mix resulted in a residual tensile strength of between 1.07 and $1.25 \mathrm{MPa}$, compared to $0.23 \mathrm{MPa}$ in plain concrete (Figure 16). A further addition of PP fibres $(0.5 \%)$ gave the highest residual strength in terms of value and percentage. The highest tensile strength was found in M6 at $1.35 \mathrm{MPa}$ with a considerably high percentage of residual strength of $40.4 \%$, which indicates that steel fibres contributed to resisting tensile forces after the exposure, and without steel fibre (M1), concrete's tensile strength is almost non-existent. 


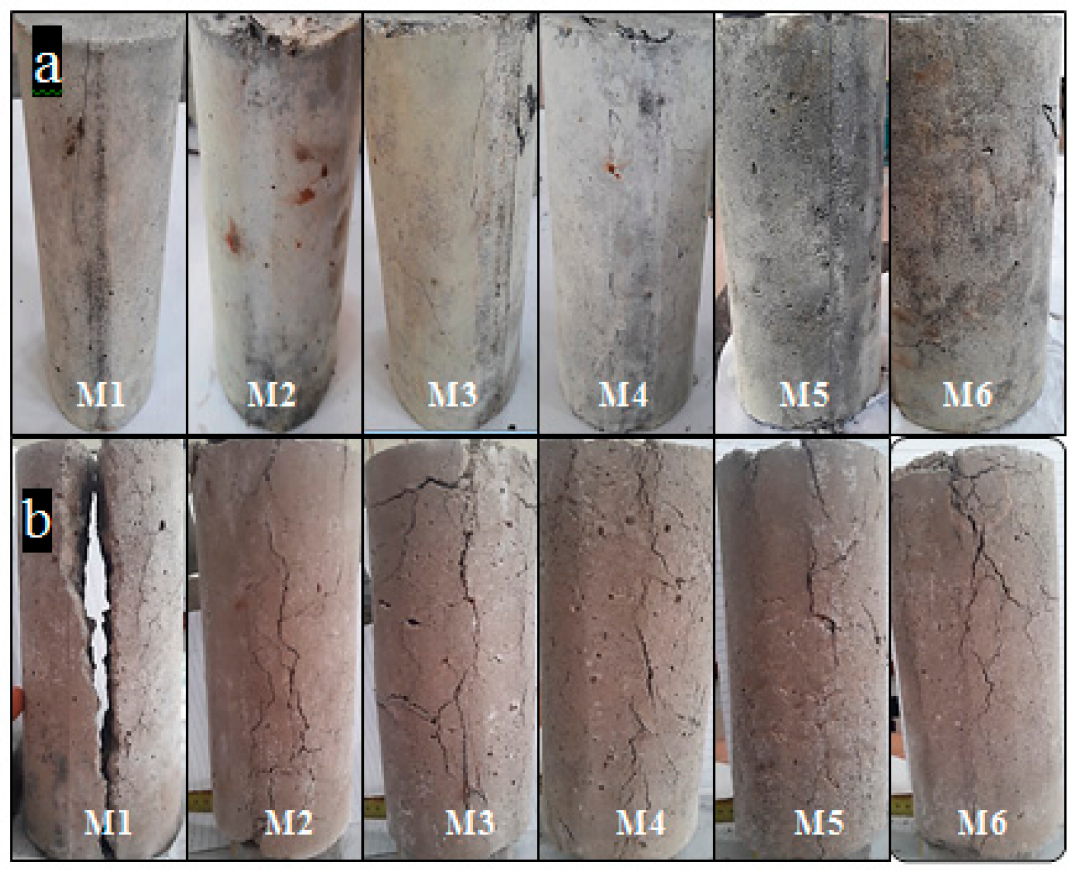

Figure 14. (a) Failure mode of cylinders at normal temperature, and (b) after the exposure to $800{ }^{\circ} \mathrm{C}$.

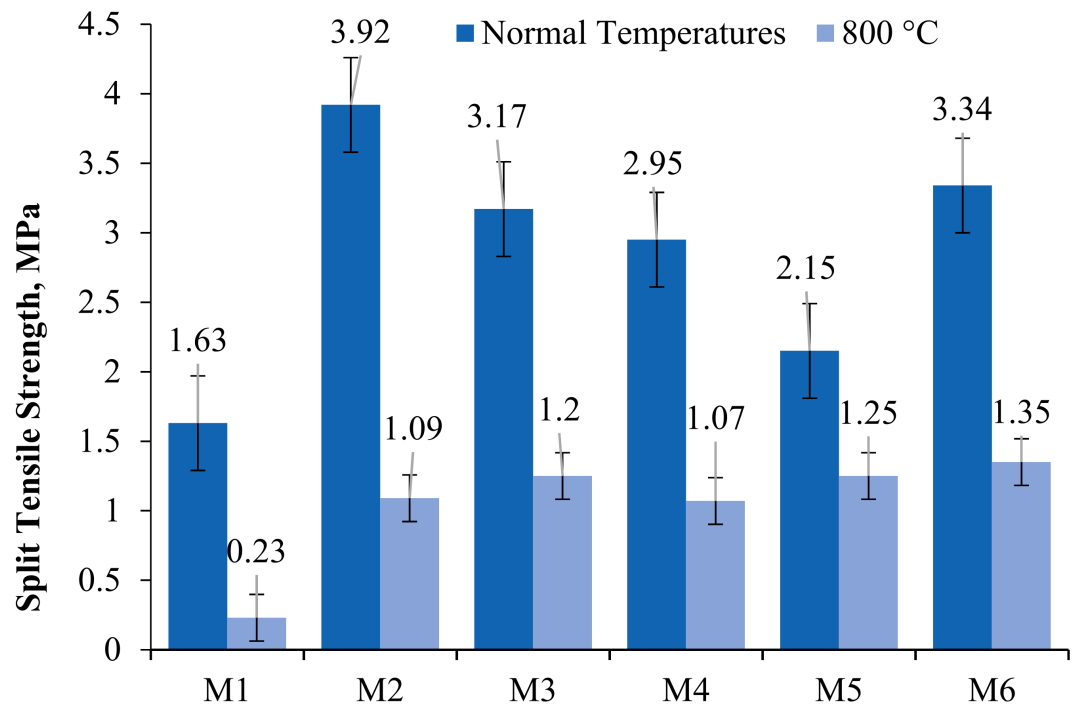

Figure 15. Split tensile strength at normal and elevated temperatures.

\subsection{Flexural Strength}

Unheated samples of plain concrete (M1) showed brittle failure characteristics, while samples with fibres showed a ductile failure without any clear separation of beams (Figure 17). This ductility is due to the bridging effect provided by steel and PP fibres. After the exposure to $800^{\circ} \mathrm{C}$, the mode of failure was very similar to the beams at normal temperature, with only M1 splitting up into two pieces. Samples with long PP fibres (M3) recorded the highest flexural strength at $12.6 \mathrm{MPa}$, followed by samples with $5 \mathrm{DH}$ steel fibres only (M6), as shown in Figure 18. Sample M4 had considerably low strength at 6.1 MPa, and this indicates that the addition of short PP fibre reduces the flexural strength of concrete, as it displaced the concrete microstructure and failed to bridge cracks at a larger force and displacement. On the other hand, long PP fibre has a higher elastic modulus with sufficient dimensions to bridge the cracks along with 5DH steel fibres because of the interlocking between the hooks and concrete matrix [47]. The hybridization of PL and 
PS at $0.25 \%$ did not show a notable increase but surprisingly, increasing this percentage to 0.5 showed a significant increase from 8.1 to $9.95 \mathrm{MPa}$. Furthermore, the sounds of steel fibres breaking up can be heard when the samples approached peak load, which supports the finding from previous observations by Abdallah [67], who stated that steel fibres will fail in tension rather than debonding or slipping, especially when the strength of the concrete matrix is high. At an elevated temperature, one sample for M1 and M6 was not severely spalled and was tested. M5 gave the highest residual flexural strength at $3.77 \mathrm{MPa}$ (37.88\%) (Figure 19), despite not having the highest strength before heating because, as mentioned before, the continuous microchannel released internal vapor pressure, leaving a better microstructure to resist flexural deformation.

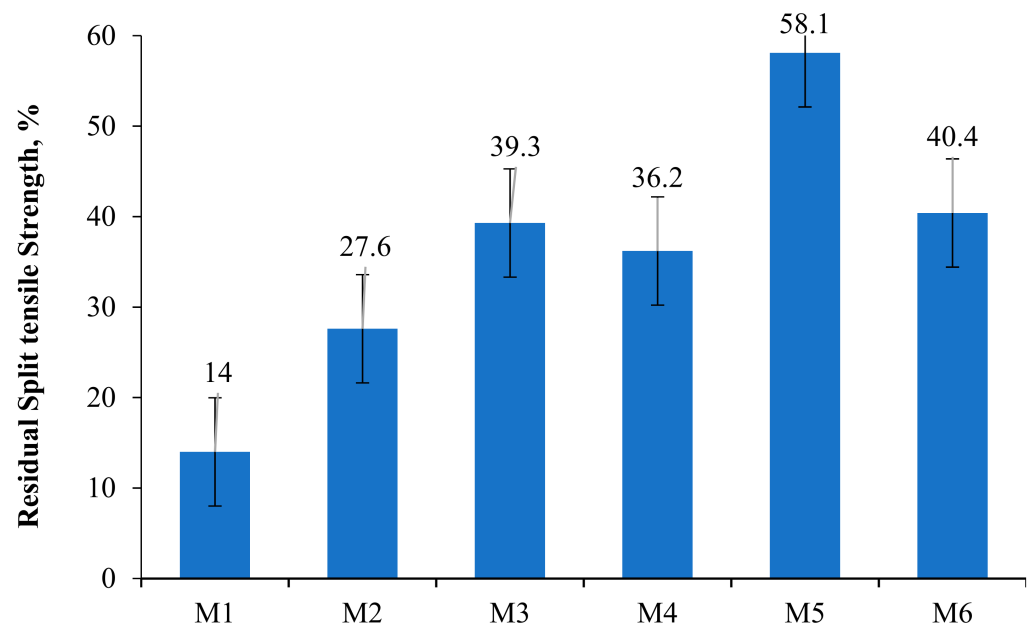

Figure 16. Residual split tensile strength.

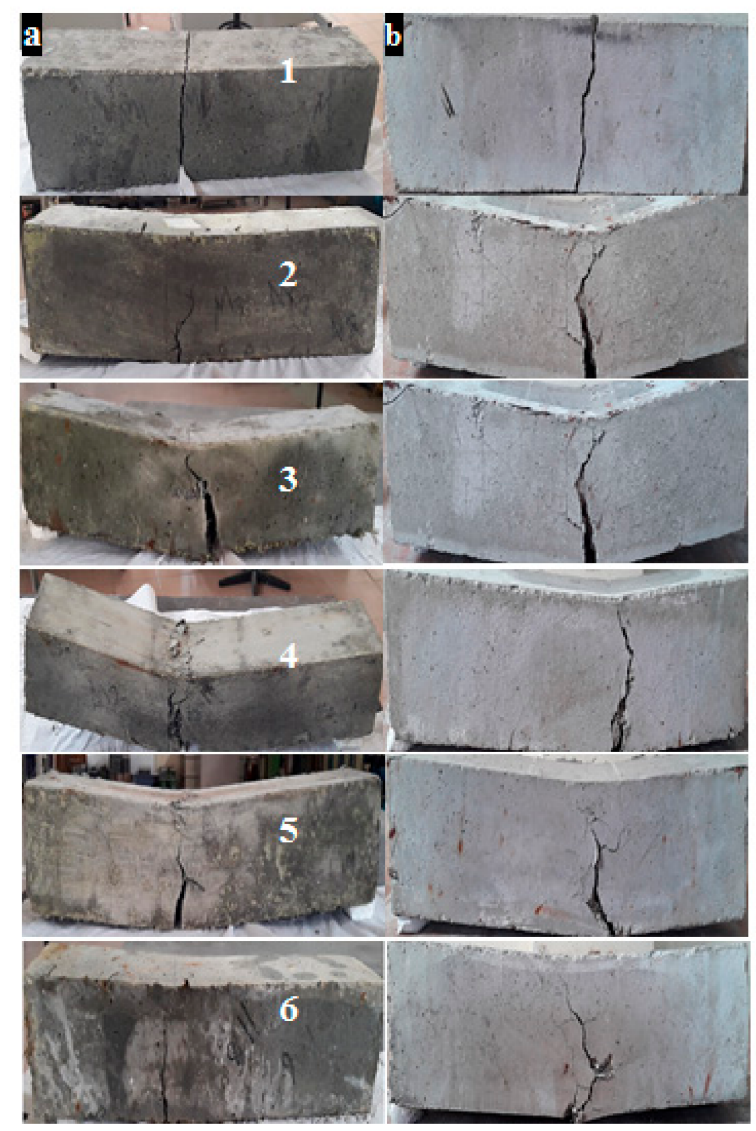

Figure 17. (a) Failure mode of beams at normal temperature and (b) after the exposure to $800{ }^{\circ} \mathrm{C}$. 


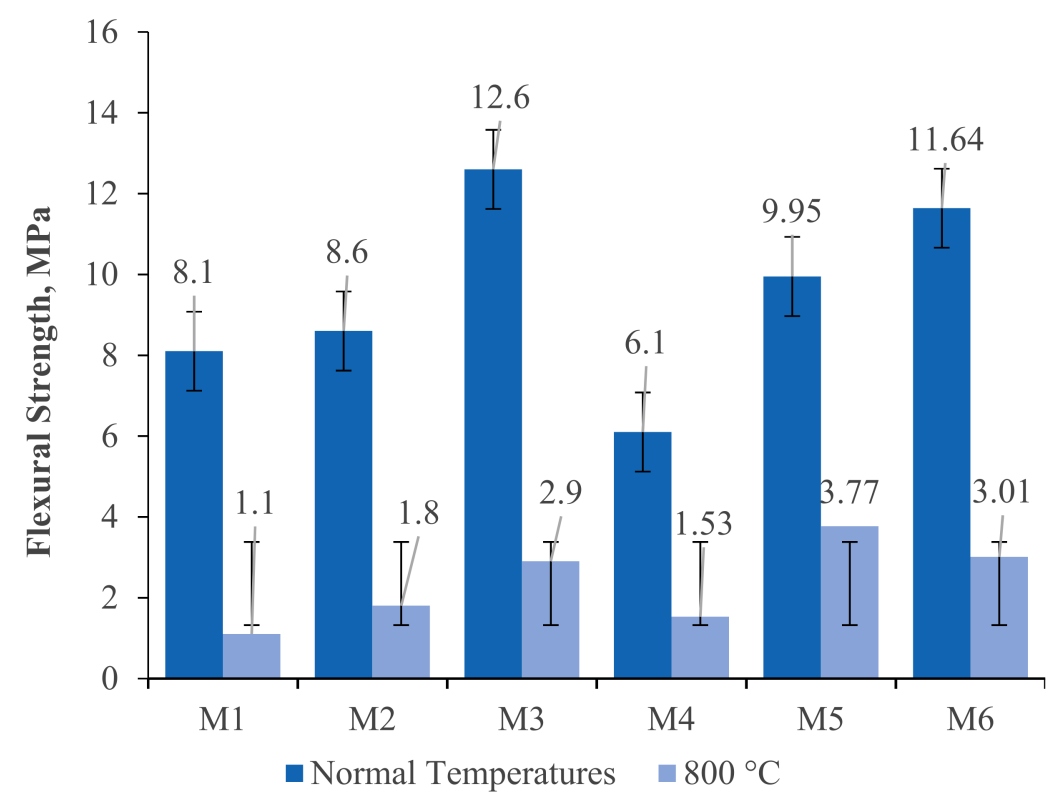

Figure 18. Flexural Strength at normal and elevated temperatures.

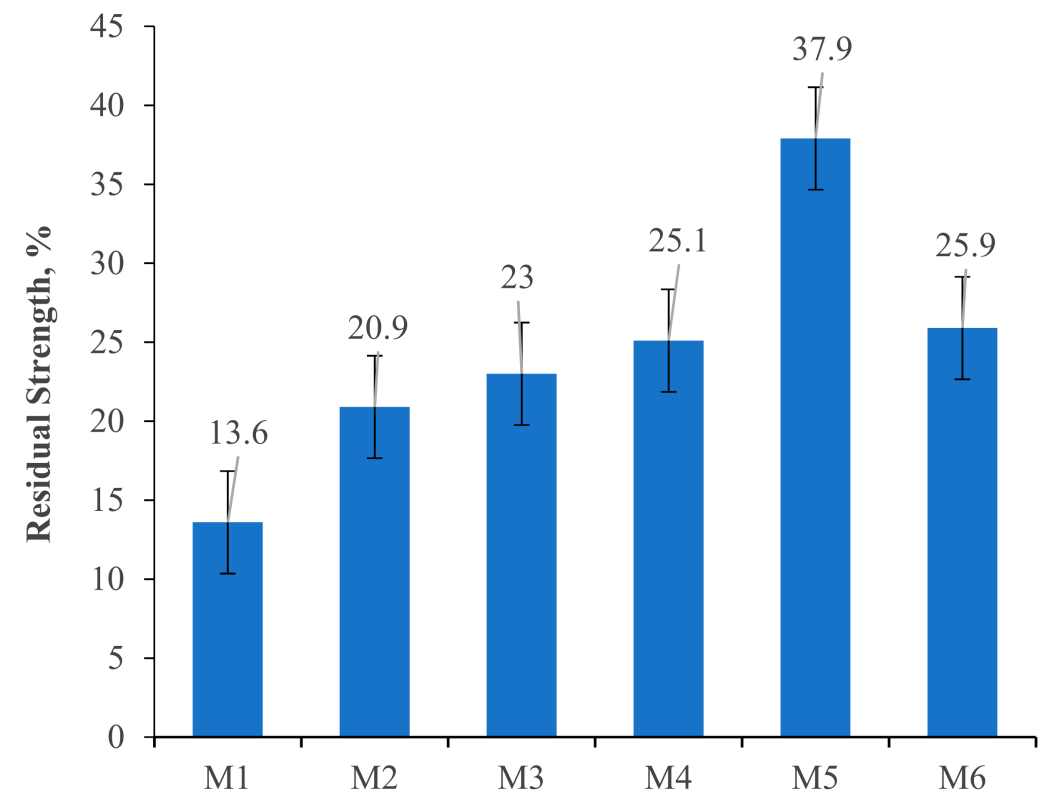

Figure 19. Residual flexural tensile strength.

Decreasing the percentage of hybrid PP fibres from $0.5 \%$ to $0.25 \%$ gave a low flexural strength $(1.8 \mathrm{MPa})$, which is similar to the mixture with short PP fibres. Samples with long PP fibres or steel fibres only (M3 and M6) recorded about 3 and $3.8 \mathrm{MPa}$, respectively, which is about twice the strength of M2 and M4. Decreasing this percentage to $25 \%$ gave a low flexural strength, $(1.8 \mathrm{MPa})$ which is similar to the mixture with short PP fibres. Samples with long PP fibres or steel fibres only (M3 and M6) recorded about 3 and 3.8 MPa, respectively, which is about twice the strength of M2 and M4. Figure 19 demonstrates the failure mode of beams at a normal temperature and after the exposure to $800{ }^{\circ} \mathrm{C}$, respectively.

\section{Conclusions}

The deterioration of concrete's integrity under elevated temperature requires an alteration in its composition to have better thermal stability. Research on fibre-reinforced concrete indicated notable improvements in the concrete strengths. This paper aimed to 
investigate the influence of steel and propylene fibres mixture on HPC behaviour after exposure to elevated temperatures. Six types of HPC were made to study these aspects with three types of fibres (5D hooked steel, short propylene $(9 \mathrm{~mm}$ ) and long propylene $(54 \mathrm{~mm})$ with different percentages of these fibres in each mix. The cast samples were heated to the targeted temperature of $800{ }^{\circ} \mathrm{C}$ at 28 days and cooled down naturally to the laboratory temperature. The visual inspection, flexural, split tensile and compressive strengths were conducted before and after the exposure to elevated temperatures. Finally, based on the major findings of this study, the conclusions have been drawn, as follows:

- There is an apparent link between adding more PP fibres and mass loss of concrete, which showed that increasing the inclusion of PP fibres helped the free water to evaporate easily through the channels in the concrete matrix.

- The incorporation of PP fibres in HPC reduced the compressive strength slightly, but increased its heat resistance in terms of residual compressive strength after the exposure to $800^{\circ} \mathrm{C}$.

- The hybridization of 5DH steel and two-length PP fibres with a percentage of $1 \%$ and $0.125 \%$ respectively, increased the split tensile strength and improved the residual strength as a percentage or value.

- Long PP fibres gave a better flexural performance and maintained $23 \%$ of the concrete's strength after the exposure.

- 5DH steel fibres improved the mechanical performance considerably.

- $5 \mathrm{DH}$ steel fibres kept the integrity of concrete after exposure to elevated temperatures for cubes and cylinders only

- PP fibres helped in mitigating the explosive spalling completely and reduced thermal cracks. However, steel fibres cannot reduce the pore pressure effectively, and two samples showed an explosive spalling.

Furthermore, the continuation of this research is in progress to perform numerous experimental tests to investigate the mechanical properties and cracks after heating. It is also recommended to study the microstructural properties (or changes) due to heating using X-ray topography or SEM. Additionally, more research on the adhesion (to the concrete substrate) and durability of microfiber reinforced green concrete mortars for rehabilitation is required, and further research into the long-term time-dependent features of concrete, incorporating recycled fibres, such as shrinkage and creep, is also needed.

Author Contributions: Conceptualization, M.M. and R.S.M.R.; Data curation, M.M., R.S.M.R., M.A., R.F., N.V. and S.K.; Formal analysis, M.M. and M.A.; Funding acquisition, M.A., R.F., N.V. and S.K.; Investigation, M.M. and R.S.M.R.; Methodology, M.M. and R.S.M.R.; Project administration, N.V.; Resources, R.S.M.R., M.A. and S.K.; Software, R.F. and N.V.; Supervision, R.S.M.R.; Validation, R.S.M.R., M.A., R.F., N.V. and S.K.; Writing-original draft, M.M.; Writing-review \& editing, R.S.M.R., M.A., R.F., N.V. and S.K. All authors have read and agreed to the published version of the manuscript.

Funding: The experimental works were supported by University Putra Malaysia. Also, the research is partially funded by the Ministry of Science and Higher Education of the Russian Federation as part of World-class Research Center program: Advanced Digital Technologies (contract No. 075-15-2020-934 dated 17 November 2020).

Institutional Review Board Statement: Not applicable.

Informed Consent Statement: Not applicable.

Data Availability Statement: Data sharing not applicable.

Acknowledgments: The authors gratefully acknowledge the financial support by the University Putra Malaysia and the assistance provided by the Department of Civil Engineering, College of Engineering, Prince Sattam Bin Abdulaziz University, Saudi Arabia; and the Department of Civil Engineering, Faculty of Engineering and IT, Amran University, Yemen, for this study.

Conflicts of Interest: The authors declare no conflict of interest. 


\section{References}

1. Williams, K.C.; Partheeban, P.; Kala, F.T. Mechanical properties of high performance concrete mechanical properties of high performance concrete incorporating granite powder as fine aggregate. Int. J. Des. Manuf. Technol. 2008, 2, 67-73. [CrossRef]

2. Haridharan, M.; Matheswaran, S.; Murali, G.; Abid, S.R.; Fediuk, R.; Amran, Y.M.; Abdelgader, H.S. Impact response of two-layered grouted aggregate fibrous concrete composite under falling mass impact. Constr. Build. Mater. 2020, $263,120628$. [CrossRef]

3. Murali, G.; Abid, S.R.; Amran, Y.M.; Abdelgader, H.S.; Fediuk, R.; Susrutha, A.; Poonguzhali, K. Impact performance of novel multi-layered prepacked aggregate fibrous composites under compression and bending. Structures 2020, 28, 1502-1515. [CrossRef]

4. Afroughsabet, V.; Biolzi, L.; Ozbakkaloglu, T. High-performance fiber-reinforced concrete: A review. J. Mater. Sci. 2016, 51, 6517-6551. [CrossRef]

5. Lesovik, V.; Voronov, V.; Glagolev, E.; Fediuk, R.; Alaskhanov, A.; Amran, Y.M.; Murali, G.; Baranov, A. Improving the behaviors of foam concrete through the use of composite binder. J. Build. Eng. 2020, 31, 101414. [CrossRef]

6. Amran, M.; Fediuk, R.; Vatin, N.; Lee, Y.H.; Murali, G.; Ozbakkaloglu, T.; Klyuev, S.; Alabduljabber, H. Fibre-reinforced foamed concretes: A review. Materials 2020, 13, 4323. [CrossRef] [PubMed]

7. Amran, Y.M.; Alyousef, R.; Alabduljabbar, H.; Khudhair, M.; Hejazi, F.; Alaskar, A.; Alrshoudi, F.; Siddika, A. Performance properties of structural fibred-foamed concrete. Results Eng. 2020, 5, 100092. [CrossRef]

8. Féron, C.; Autuori, P.; Bessière, C.; Joyeux, D. Vers des moyens de prévenir l'écaillage du béton en tunnel. Tunn. Ouvrages Souterr. 2006, 196, 228-235.

9. Raj, B.; Sathyan, D.; Madhavan, M.K.; Raj, A. Mechanical and durability properties of hybrid fiber reinforced foam concrete. Constr. Build. Mater. 2020, 245, 118373. [CrossRef]

10. Jin, L.; Zhang, R.; Dou, G.; Xu, J.; Du, X. Experimental and numerical study of reinforced concrete beams with steel fibers subjected to impact loading. Int. J. Damage Mech. 2017, 27, 1058-1083. [CrossRef]

11. Fediuk, R. High-strength fibrous concrete of Russian Far East natural materials. IOP Conf. Ser. Mater. Sci. Eng. 2016, 116, 012020. [CrossRef]

12. Ahmed, R.H.; Abdel-Hameed, G.D.; Farahat, A.M. Behavior of hybrid high-strength fiber reinforced concrete slab-column connections under the effect of high temperature. HBRC J. 2016, 12, 54-62. [CrossRef]

13. Abid, S.R.; Murali, G.; Amran, M.; Vatin, N.; Fediuk, R.; Karelina, M. Evaluation of mode II fracture toughness of hybrid fibrous geopolymer composites. Materials 2021, 14, 349. [CrossRef] [PubMed]

14. Song, P.; Hwang, S. Mechanical properties of high-strength steel fiber-reinforced concrete. Constr. Build. Mater. 2004, 18, 669-673. [CrossRef]

15. Jang, S.-J.; Yun, H.-D. Combined effects of steel fiber and coarse aggregate size on the compressive and flexural toughness of high-strength concrete. Compos. Struct. 2018, 185, 203-211. [CrossRef]

16. Gao, D.; Zhang, L.; Nokken, M. Mechanical behavior of recycled coarse aggregate concrete reinforced with steel fibers under direct shear. Cem. Concr. Compos. 2017, 79, 1-8. [CrossRef]

17. Ahmed, G.M.A.A.; Fedyuk, R.S.; Liseytsev, Y.L.; Timokhin, R.A. Use of Iraq concrete scrap as filler and aggregate of heavyweight and lightweight concrete. Constr. Mater. Prod. 2020, 3, 28-39. [CrossRef]

18. Amran, Y.H.M. Influence of structural parameters on the properties of fibred-foamed concrete. Innov. Infrastruct. Solut. 2020, 5, 1-18. [CrossRef]

19. Murali, G.; Abid, S.R.; Abdelgader, H.S.; Amran, Y.H.M.; Shekarchi, M.; Wilde, K. Repeated projectile impact tests on multi-layered fibrous cementitious composites. Int. J. Civ. Eng. 2021, 19, 635-651. [CrossRef]

20. Markovic, I. High-Performance Hybrid-Fibre Concrete: Development and Utilisation; IOS Press: Washington, DC, USA, 2006.

21. Fediuk, R.S.; Ibragimov, R.A.; Lesovik, V.S.; Pak, A.A.; Krylov, V.V.; Poleschuk, M.M.; Stoyushko, N.Y.; Gladkova, N.A. Processing equipment for grinding of building powders. IOP Conf. Ser. Mater. Sci. Eng. 2018, 327, 042029. [CrossRef]

22. Jaishankar, P.; Murali, G.; Salaimanimagudam, M.P.; Amran, Y.H.M.; Fediuk, R.; Karthikeyan, K. Study of topology optimized hammerhead pier beam made with novel preplaced aggregate fibrous concrete. Period. Polytech. Civ. Eng. 2020, 65, 287-298. [CrossRef]

23. Peng, G.-F.; Huang, Z.-S. Change in microstructure of hardened cement paste subjected to elevated temperatures. Constr. Build. Mater. 2008, 22, 593-599. [CrossRef]

24. Kalifa, P.; Chéné, G.; Gallé, C. High-temperature behaviour of HPC with polypropylene fibres: From spalling to microstructure. Cem. Concr. Res. 2001, 31, 1487-1499. [CrossRef]

25. Ramakrishnan, K.; Depak, S.; Hariharan, K.; Abid, S.R.; Murali, G.; Cecchin, D.; Fediuk, R.; Amran, Y.M.; Abdelgader, H.S.; Khatib, J.M. Standard and modified falling mass impact tests on preplaced aggregate fibrous concrete and slurry infiltrated fibrous concrete. Constr. Build. Mater. 2021, 298, 123857. [CrossRef]

26. Li, Y.; Lu, X.; Guan, H.; Ying, M.; Yan, W. A case study on a fire-induced collapse accident of a reinforced concrete frame-supported masonry structure. Fire Technol. 2015, 52, 707-729. [CrossRef]

27. Abdul-Rahman, M.; Al-Attar, A.A.; Hamada, H.M.; Tayeh, B. Microstructure and structural analysis of polypropylene fibre reinforced reactive powder concrete beams exposed to elevated temperature. J. Build. Eng. 2020, 29, 101167. [CrossRef]

28. Wald, F.; Chlouba, J.; Uhl1, A.; Kallerova, P.; Stujberova, M. Temperatures during fire tests on structure and its prediction according to Eurocodes. Fire Saf. J. 2009, 44, 135-146. [CrossRef] 
29. Ma, Q.; Guo, R.; Zhao, Z.; Lin, Z.; He, K. Mechanical properties of concrete at high temperature-A review. Constr. Build. Mater. 2015, 93, 371-383. [CrossRef]

30. Chang, Y.; Chen, Y.; Sheu, M.; Yao, G. Residual stress-strain relationship for concrete after exposure to high temperatures. Cem. Concr. Res. 2006, 36, 1999-2005. [CrossRef]

31. Bessmertnyi, V.S.; Lesovik, V.S.; Krokhin, V.P.; Puchka, O.V.; Nikiforova, E.P. The reducing effect of argon in the plasma treatment of high-melting nonmetallic materials (A review). Glas. Ceram. 2002, 58, 362-364. [CrossRef]

32. Kalifa, P.; Menneteau, F.-D.; Quenard, D. Spalling and pore pressure in HPC at high temperatures. Cem. Concr. Res. 2000, 30, 1915-1927. [CrossRef]

33. Elistratkin, M.Y.; Lesovik, V.S.; Zagorodnjuk, L.H.; Pospelova, E.A.; Shatalova, S.V. New point of view on materials development. IOP Conf. Ser. Mater. Sci. Eng. 2018, 327, 032020. [CrossRef]

34. Bažant, Z.P. Analysis of pore PRESSURE, Thermal stress and FRACTURE in Rapidly Heated Concrete. In Proceedings of the International Workshop on Fire Performance of High-Strength Concrete, Gaithersburg, MD, USA, 13-14 February 1997; Available online: https: / / tsapps.nist.gov/publication/get_pdf.cfm?pub_id=916655 (accessed on 15 July 2021).

35. Atkinson, T. Polypropylene fibers control explosive spalling in high-performance concrete. Concrete 2004, 38, 69-70.

36. Xiao, J.; Falkner, H. On residual strength of high-performance concrete with and without polypropylene fibres at elevated temperatures. Fire Saf. J. 2006, 41, 115-121. [CrossRef]

37. Noumowé, A. Mechanical properties and microstructure of high strength concrete containing polypropylene fibres exposed to temperatures up to $200^{\circ} \mathrm{C}$. Cem. Concr. Res. 2005, 35, 2192-2198. [CrossRef]

38. Taerwe, L. RILEM Technical Committee HTC, State of the Art Report; CRC Press: London, UK, 2004; p. 736.

39. Chernysheva, N.; Lesovik, V.; Fediuk, R.; Vatin, N. Improvement of performances of the gypsum-cement fiber reinforced composite (GCFRC). Materials 2020, 13, 3847. [CrossRef] [PubMed]

40. Fedorov, V.; Mestnikov, A. Influence of cellulose fibers on structure and properties of fiber reinforced foam concrete. MATEC Web Conf. 2018, 143, 02008. Available online: https://www.matec-conferences.org/articles/matecconf/abs/2018/02/matecconf_ yssip2017_02008/matecconf_yssip2017_02008.html (accessed on 17 July 2021). [CrossRef]

41. Murali, G.; Abid, S.R.; Karthikeyan, K.; Haridharan, M.; Amran, M.; Siva, A. Low-velocity impact response of novel prepacked expanded clay aggregate fibrous concrete produced with carbon nano tube, glass fiber mesh and steel fiber. Constr. Build. Mater. 2021, 284, 122749. [CrossRef]

42. Bei, S.; Zhixiang, L. Investigation on spalling resistance of ultra-high-strength concrete under rapid heating and rapid cooling. Case Stud. Constr. Mater. 2016, 4, 146-153. [CrossRef]

43. Ding, Y.; Azevedo, C.M.; Aguiar, J.; Jalali, S. Study on residual behaviour and flexural toughness of fibre cocktail reinforced self compacting high performance concrete after exposure to high temperature. Constr. Build. Mater. 2012, 26, 21-31. [CrossRef]

44. Ding, Y.N.; Wang, Y.H.; Zhang, Y.L. Investigation on Toughness of Fibre Cocktail Reinforced Self Consolidating Concrete after High Temperature. Mater. Sci. Forum 2010, 650, 67-77. [CrossRef]

45. Pliya, P.; Beaucour, A.-L.; Noumowé, A. Contribution of cocktail of polypropylene and steel fibres in improving the behaviour of high strength concrete subjected to high temperature. Constr. Build. Mater. 2010, 25, 1926-1934. [CrossRef]

46. Bošnjak, J.; Sharma, A.; Grauf, K. Mechanical properties of concrete with steel and polypropylene fibres at elevated temperatures. Fibers 2019, 7, 9. [CrossRef]

47. Pliya, P.; Beaucour, A.L.; Noumowé, A. Strength and porosity of concrete incorporating polypropylene and steel fibres subjected to high temperature. In Proceedings of the 20th International Conference on Structural Mechanics in Reactor Technology (SMiRT 20), Helsinki, Finland, 9-14 August 2009; Available online: https:/ / repository.lib.ncsu.edu/bitstream/handle/1840.20/23593/1_ paper_2024.pdf?sequence=1\&isAllowed=y (accessed on 15 July 2021).

48. Adnan, A.; Suradi, S. Comparison on the effect of earthquake and wind loads on the, performance of reinforced concrete buildings. In Proceedings of the 14th World Conference on Earthquake Engineering, Kuala Lumpur, Malaysia, 2-4 October 2008; pp. 1-3.

49. Suhaendi, S.L.; Horiguchi, T. Effect of short fibers on residual permeability and mechanical properties of hybrid fibre reinforced high strength concrete after heat exposition. Cem. Concr. Res. 2006, 36, 1672-1678. [CrossRef]

50. Fediuk, R.; Mosaberpanah, M.A.; Lesovik, V. Development of fiber reinforced self-compacting concrete (FRSCC): Towards an efficient utilization of quaternary composite binders and fibers. Adv. Concr. Constr. 2020, 9, 387-395.

51. ASTM C150M-15, A.C. Standard Specification for Portland Cement; ASTM International: West Conshohocken, PA, USA, 2015.

52. ASTM C1240-20. Standard Specification for Silica Fume Used in Cementitious Mixtures; ASTM International: West Conshohocken, PA, USA, 2011.

53. ASTM C33/C33M-18. Standard Specification for Concrete Aggregates; ASTM International: West Conshohocken, PA, USA, 2008.

54. Lee, S.-J.; Yoo, D.-Y.; Moon, D.-Y. Effects of hooked-end steel fiber geometry and volume fraction on the flexural behavior of concrete pedestrian decks. Appl. Sci. 2019, 9, 1241. [CrossRef]

55. ACI 211-91. Standard Practice for Selecting Proportions for Normal, Heavyweight, and Mass Concrete. American Concrete Institute. Committee (ACI) Committee 211. 1991. Available online: https:/ / kashanu.ac.ir/Files/aci\%20211_1_91.pdf (accessed on 17 July 2021).

56. Dawood, E.; Ramli, M. Contribution of hybrid fibers on the properties of high strength concrete having high workability. Procedia Eng. 2011, 14, 814-820. [CrossRef] 
57. $\mathrm{Wu}, \mathrm{H} . ; \mathrm{Lin}, \mathrm{X} . ; \mathrm{Zhou}, \mathrm{A}$. A review of mechanical properties of fibre reinforced concrete at elevated temperatures. Cem. Concr. Res. 2020, 135, 106117. [CrossRef]

58. ASTM C496. Standard Test Method for Splitting Tensile Strength of Cylindrical Concrete Specimens, American Standards for Testing and Materials; ASTM International: West Conshohocken, PA, USA, 2011.

59. ASTM C78. Standard Test Method for Flexural Strength of Concrete (Using Simple Beam with Third-Point Loading), American Standards for Testing and Materials; ASTM International: West Conshohocken, PA, USA, 2010.

60. BS EN 12390-3. Testing Hardened Concrete Part 3: Compressive Strength of Test Specimens. British Standards Institution. 2009, pp. 12390-12393. Available online: https:/ / pdfcoffee.com/bs-en-12390-3-5-pdf-free.html (accessed on 15 July 2021).

61. Salaimanimagudam, M.P.; Murali, G.; Vardhan, C.M.V.; Amran, M.; Vatin, N.; Fediuk, R.; Vasilev, Y. Impact response of preplaced aggregate fibrous concrete hammerhead pier beam designed with topology optimization. Crystals 2021, 11, 147. [CrossRef]

62. Murali, G.; Amran, M.; Fediuk, R.; Vatin, N.; Raman, S.N.; Maithreyi, G.; Sumathi, A. Structural behavior of fibrous-ferrocement panel subjected to flexural and impact loads. Materials 2020, 13, 5648. [CrossRef] [PubMed]

63. Murali, G.; Abid, S.; Amran, M.; Fediuk, R.; Vatin, N.; Karelina, M. Combined effect of multi-walled carbon nanotubes, steel fibre and glass fibre mesh on novel two-stage expanded clay aggregate concrete against impact loading. Crystals 2021, 11, 720. [CrossRef]

64. Hertz, K.D. Danish investigations on silica fume concretes at elevated temperatures. Mater. J. 1992, 89, 345-347. [CrossRef]

65. Richardson, A.E. Compressive strength of concrete with polypropylene fibre additions. Struct. Surv. 2006, 24, 138-153. [CrossRef]

66. Naser, M.Z.; Hawileh, R.A.; Abdalla, J.A. Fiber-reinforced polymer composites in strengthening reinforced concrete structures: A critical review. Eng. Struct. 2019, 198, 109542. [CrossRef]

67. Abdallah, M.S. Bonding Mechanisms and Strength of Hooked—End Steel Fibre Reinforced Cementitious Composites. Ph.D. Thesis, Brunel University Archive, London, UK, 2017. 